\title{
Aptiekas asistentu istaba Farmācijas muzeja ekspozīcijā
}

Zāḷu gatavošana ir vissenākā aptiekas funkcija. Ilgu laiku tā bija arī aptiekas galvenais uzdevums. Lai arī samazinātā veidā, tā saglabājusies līdz pat mūsu dienām.

Pēckara periodā, kad Latvija bija iekḷauta PSRS sastāvā, iedzīvotājus ar zāḷu līdzekḷiem apgādāja plašs aptieku un aptieku punktu tīkls. 1963. gadā aptieku un aptieku punktu kopskaits Latvijā sasniedza 891. To pamatuzdevums bija apgādāt iedzīvotājus, kā arī ārstnieciskās un profilaktiskās iestādes ar zāḷu līdzekļiem, pārsienamo materiālu, slimnieku kopšanas priekšmetiem un higiēnas piederumiem. Aptieku pienākumos joprojām ietilpa arī zāḷu gatavošana pēc individuāliem recepšu priekšrakstiem. To veica īpaši iekārtotajā telpā - asistentu istabā. Ar zāḷu gatavošanu, pagatavoto zāḷu kontroli un izsniegšanu nodarbojās vairāki aptiekas darbinieki, kuri lielajās aptiekās strādāja pat divās maiņās.

Recepti no slimnieka pien̦ēma receptārs, kurš pārbaudīja receptes atbilstību zāḷu sastāvam, receptē parakstīto stipri iedarbīgo vielu devas, receptes noformējumu un derīguma termiņu. Receptārs novērtēja arī zāḷu saderību, aprēķināja cenu un izsniedza slimniekam kvīti par pasūtījumu. Bet recepti zāļu pagatavošanai receptārs nodeva asistentam, lai viņš medikamentus pagatavo tieši pēc ārsta norādījuma.

Pagatavoto zāļu kvalitāti noteica ķ̄imiķis analītiķis, kura darba vieta arī bija iekārtota asistentu istabā. Zāļu un izejvielu pārbaudei izmantoja fizikālās, ķīmiskās, organoleptiskās pārbaudes metodes. Izvēles kārtībā tika pārbaudītas arī asistentu pagatavotās zāles, sevišksu uzmanību veltījot koncentrētajiem šksīdumiem, acu pilieniem, medikamentiem, kas satur 
indīgās un stipri iedarbīgās vielas, zālēm, kas paredzētas jaundzimušajiem. Analītiķis pārbaudīja arī bērniem paredzēto zāļu garšu, oftalmoloǵiskos šķ̄idumus (vai tie nesatur mehāniskus piemaisījumus), etilspirta koncentrāciju un destilētā ūdens kvalitāti.

Pēc tam kontrolieris salīdzināja receptes priekšrakstu ar t. s. pasi dokumentu, kurā asistents norādīja, kādas izejvielas un cik daudz viņš izmantojis, lai pagatavotu konkrēto zāḷu formu, bet asignētājam bija jāizraksta receptes kopija - signatūra, kuru kopā ar pagatavoto medikamentu pielīmēja pie iesaiņojuma ar attiecīgu etiķeti. Kontrolieris noformēja pagatavotās zāles un nodeva tās receptāram, kurš tās izsniedza slimniekam, paskaidrojot medikamenta lietošanu.

Par zāḷu izejmateriālu rezervēm, papildinot ar tām stāvtraukus asistentu istabā, lai asistentam vienmēr būtu viss darbam nepieciešamais, atbildīgs bija defektārs, kurš gatavoja arī koncentrētos šķīdumus un iepildīja tos birešu sistēmā.

Fasētāju uzdevums bija veikt mazkvalificētus darbus, palīdzot defektāram un asistentam sasvērt sīkākās vienībās preparātus, kas aptiekai piegādāti nefasētā veidā, kā arī sasvērt pulverus vai šķ̄īdumus.

Zāḷu gatavošana notika asistentu istabā, kur - atkarībā no darba rakstura - bija iekārtotas un aprīkotas darba vietas šksidro, mīksto un cieto medikamentu formu pagatavošanai, zāḷu un destilētā ūdens analīzei, kā arī fasēšanai. Šī telpa bija aprīkota ar īpašiem traukiem un iekārtām, kā arī speciāliem dažādas konstrukcijas asistentu galdiem. Uz tiem un asistenta darba vietas tuvumā tika novietotas grozules, kur atradās stāvtrauki (speciāli aptiekas trauki, kuros uzglabā izejvielas zālu gatavošanai) ar izejvielām. Traukiem bija jābūt ērti lietojamiem darba procesā - ērti satveramiem un noturamiem vienā rokā, ar skaidri salasāmiem uzrakstiem. Trauku izmēram bija jāatbilst attiecīgā medikamenta patēriņam vismaz vienai darba dienai.

Indīgo vielu stāvtraukus noformēja ar melnu etiķeti, uz kuras zāḷu nosaukumu rakstīja ar baltu krāsu, norādot augstākās vienreizējās un dienas devas. Indīgās vielas un tās saturošās zāļu formas uzglabāja speciālos skapjos ar uzrakstu "Venena" un apzīmēja ar burtu "A". Uz stipri iedarbīgo vielu stāvtraukiem nosaukumu rakstīja sarkanā krāsā uz balta fona, tāpat norādot augstākās vienreizējās un dienas devas. Šīs vielas apzīmēja ar burtu “B”. Stipri iedarbīgos līdzekḷus uzglabāja atsevišksi no citiem skapjos ar uzrakstu "Heroica". 


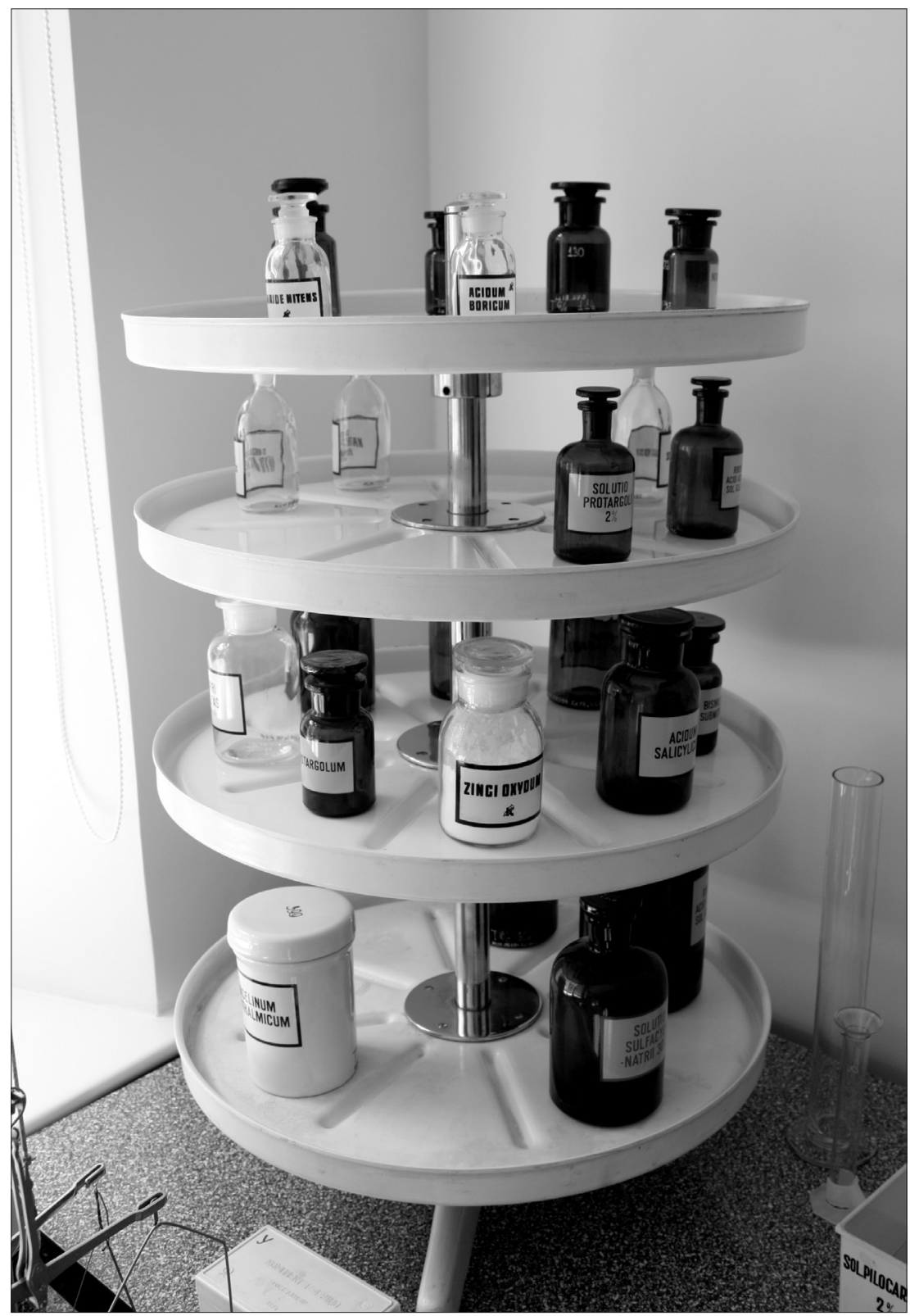

Asistenta darba vietas tuvumā tika novietotas grozules, kur atradās stāvtrauki 


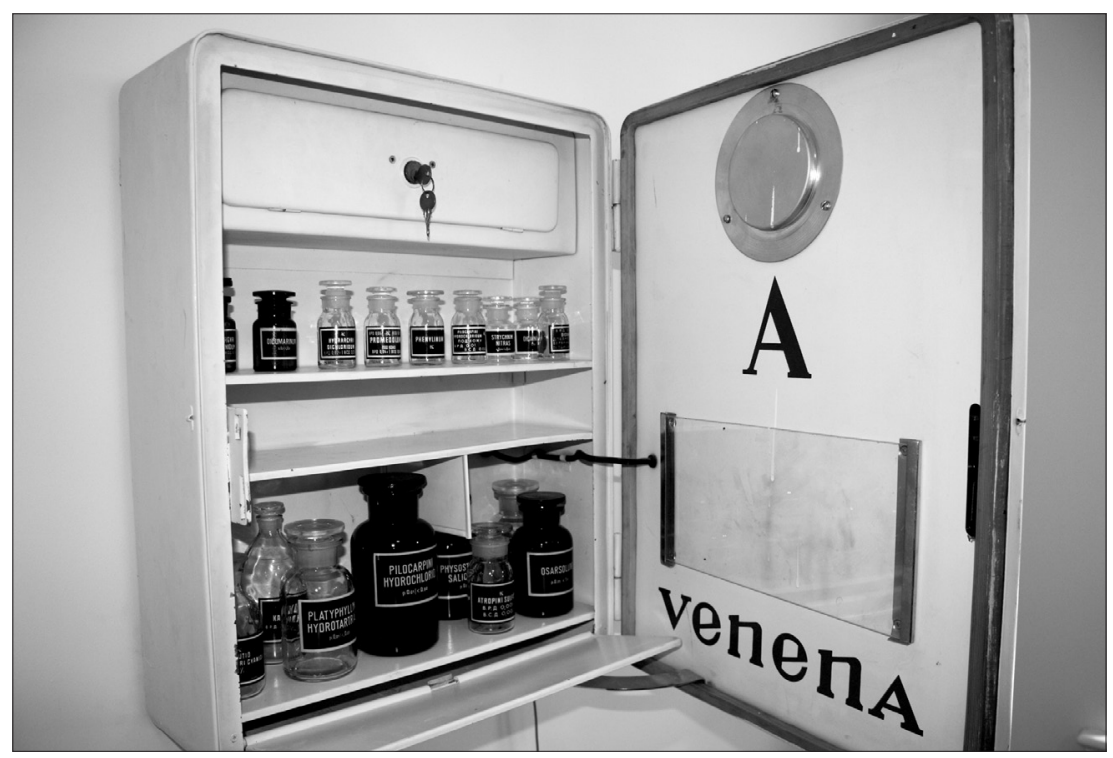

Indīgās vielas un tās saturošās zāḷu formas uzglabāja speciālos skapjos

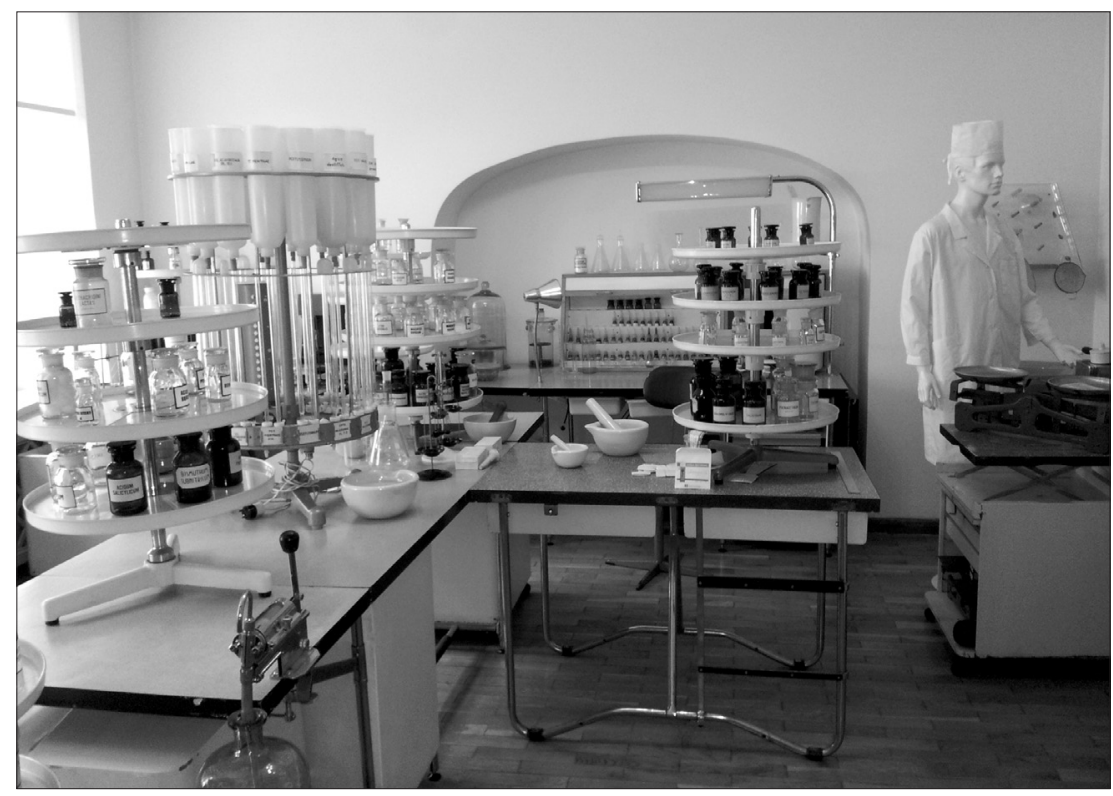

Aptiekas asistentu istabas iekārtojums 
Pārējo zāḷu vielu jeb t. s. brīvi glabājamo medikamentu stāvtraukus noformēja ar baltu etiķeti un melniem uzrakstiem. Šīs zāles turēja skapjos un grozulēs, ievērojot vispārpieņemtos uzglabāšanas noteikumus: ārīgi lietojamos medikamentus uzglabāja atsevišķi no iekšķīgi lietojamiem, šķidrumus - atsevišksi no pulverveida vielām, atsevišksi uzglabāja arī izejvielas parenterāli ievadāmo šķīdumu gatavošanai.

20. gs. pēdējos 10 gados un 21. gs. sākumā Latvijas aptiekās notika pārmaiņas. Darba specifika mainījās, lielākajā daḷā aptieku vairs negatavoja zāles, bet galvenokārt nodarbojās ar rūpnieciski ražoto medikamentu pārdošanu. Zāļu pagatavošanu kā farmaceitiskās aprūpes sastāvdaļu ir saglabājušas vairs tikai nedaudzas aptiekas.

Tādējādi padomju perioda aptieku asistentu istaba kā kultūrvēsturisks mantojums nonākusi Farmācijas muzeja ekspozīcijā.

Kopš 2006. gada, apzinot vairākas Latvijas aptiekas, tika sākta asistentu istabas eksponātu komplektēšana. Farmācijas muzeja aicinājumam atsaucās septiṇas aptiekas un divas iestādes, kuras labprāt Farmācijas muzejam nodeva asistentu istabas mēbeles, stāvtraukus, laboratorijas piederumus un ierīces. Asistentu galds un ķīmiķa analītiķa galds (divas vienības) ar visu aprīkojumu tika iegūti no Saulkrastu aptiekas. Klīniskā slimnīca “Gaiḷezers", samazinot slimnīcas vajadzībām pagatavojamo zāḷu sortimentu, nodeva muzejam birešu sistēmu, grozules, dažādas ierīces pulveru dozēšanai, šķidruma fasēšanas dozatoru un stāvtraukus (kopā 320 vienības). Ķeguma Daugavas aptieka dāvināja 302 eksponātus, tostarp aptiekas stāvtraukus, piestas un rokas svariņus. Mālpils aptieka nodeva mēbeles, grozules, svarus, stāvtraukus (kopā 50 vienības), Brocēnu aptieka - 33 dažāda lieluma aptiekas stāvtraukus, bet Inčukalna lauku ambulance - 28 stāvtraukus. 34 laboratorijas piederumus Farmācijas muzejs saṇēma no RSU Farmācijas fakultātes. Ķekavas "Mēness aptieka" nodeva divus metāla skapjus - indīgo, narkotisko un stipri iedarbīgo vielu uzglabāšanai. Visi šie eksponāti nonāca Farmācijas muzejā izveidotajā aptiekas asistentu istabā, kur tie izvietoti šādi: uz asistenta galda ir novietota grozule pulverveida zāļu vielām (16 gab.) ārīgai lietošanai, grozule pulverveida zāḷu vielām (brīvi stāvošām un stipri iedarbīgām, kopā 68 gab.) iekšksīgai lietošanai, birešu sistēma svara tilpuma koncentrēto šķīdumu mērīšanai, receptūras jeb Mora svari. Turklāt uz galda vēl ir atsvaru komplekts, dažāda izmēra rokas svariṇi, stāvtrauks ar svaru 
tīrīšanas šķīdumu, stāvtrauks vates tamponiem un destilēta ūdens stāvtrauks. Galda atvilktnēs novietoti atsvaru komplekti, rokas svarini, kraceri, kapsulatūras, papīra kapsulas pulveru svēršanai, pulvera dozatori un šksidruma dozators, bet galda skapītī - trauki ekstemporālo zāḷu formu pagatavošanai (piestas, piestalas, porcelāna blıodiņas, platkakles, piltuves un zirnīšu mašīna).

Asistentu istabā uz grīdas noliktas vairākas grozules: viena ar 47 stikla un porcelāna stāvtraukiem ārīgi lietojamiem šķidrumiem un biezas konsistences vielām (pastām, ziežu pamatiem, dažādām ellıām, kolodijiem), turpat ir vēl viena grozule ar 38 stāvtraukiem šķidriem preparātiem (tinktūrām, šķidriem ekstraktiem, koncentrātiem, šķīidumiem) iekšķīgai lietošanai un astoņi porcelāna stāvtrauki drogu uzlējumu un novārījumu pagatavošanai, bieziem augu ekstraktiem un augu pulveriem, un visbeidzot ir grozule ar 22 stāvtraukiem šksidriem preparātiem (el̦lām, spirtiem, emulgatoriem ārīgai lietošanai).

Ķīmiķa analītiķa darba vietā ir reaǵentu statīvs, vairāki statīvi biretēm, receptūras svariem, rokas svariem. Uz galda atrodas arī atsvaru komplekts, destilētā ūdens stāvtrauks, indikatori, refraktometrs. Galda atvilktnēs ir mērtrauki: mērcilindri, mērkolbas, aptiekas pipetes, Mora pipetes, kā arī Petrī plates, kolbas, stāvkolbas un piltuves ekstemporālo zāḷu formu pārbaudei.

Asistenta istabā nozīmīga ir arī darba vieta acu pilienu pagatavošanai. Tur atrodas grozule ar 18 stāvtraukiem pulverveida un šksidrām zāḷu vielām - acu ziežu pamatiem, acu pilienu un ziežu pagatavošanai. Vēl uz galda ir rokas svariņi, atsvaru komplekts, platkakles, piltuves, lampa mehānisko piemaisījumu noteikšanai, ierīce pudel̦u aizvākošanai ar alumīnija vāciņiem.

Defektāra darba vietā ir galda svari, destilētā ūdens stāvtrauks, sliepnes jeb špāteles, stikla spieķi, kilogramu atsvari, infundiera aparāts. Uz grīdas statīvā novietots balons šķidruma izliešanai (koncentrētām vielām).

Pie sienas novietoti divi stiprināmi skapji - indīgo un narkotisko vielu uzglabāšanai ("A" - "Venena") ar 18 stāvtraukiem un stipri iedarbīgo vielu ("B" - "Heroica") uzglabāšanai ar pieciem stāvtraukiem.

Vēl asistentu istabā atrodas medikamentu rezervju skapis, kurā ievietoti 190 stikla un 13 porcelāna stāvtrauki. 
Tātad pavisam kopā no iegūtajām 770 vienībām asistentu istabā izstādītas 725 vienības: 534 dažāda lieluma stikla stāvtrauki, 92 dažāda lieluma porcelāna stāvtrauki un 99 laboratorijas piederumi.

Jaunā ekspozīcija "Aptiekas asistentu istaba" tiek izmantota vairākās muzeja pedagoǵiskajās programmās, iepazīstinot apmeklētājus ar zāḷu, it īpaši pulveru, pagatavošanu.

\title{
Assistant Room in Pharmacy Museum Exposition
}

\begin{abstract}
Last 10 years of the $20^{\text {th }}$ century and $21^{\text {st }}$ century bring changes for pharmacies of Latvia. Work specialization changed and most pharmacies did not produce medicine anymore. Thus, assistant room as cultural and historical heritage from the Soviet time period deserves its place in Pharmacy Museum's exposition.

Making of the exposition took two years. In the exposition there are 770 units in collection, from which 725 are exhibited in the assistant room. The assistant room exposition is used for various pedagogical programmes held at the museum.
\end{abstract}

Inta Vegnere

Farmācijas muzejs, Rīga

farmacijasmuzejs@inbox.lv

Inguna Cīrule

Farmācijas muzejs, Rīga

farmacijasmuzejs@inbox.lv 